\title{
Detection of Xanthomonas axonopodis pv. phaseoli in bean seeds by flow cytometry, immunostaining and direct viable counting
}

\author{
Nilvanira D. Tebaldi' ${ }^{1}$, Jeroen Peters ${ }^{2}$, Ricardo M. Souza ${ }^{1}$, Luiz G. Chitarra ${ }^{3}$, Patricia van der Zouwen ${ }^{2}$, Jan \\ Bergervoet $^{2}$ \& Jan van der Wolf ${ }^{2}$
}

${ }^{1}$ Departamento de Fitopatologia, Universidade Federal de Lavras, 37200-000, Lavras, MG, Brazil; ${ }^{2}$ Plant Research International, 6700 AA, Wageningen, The Netherlands; ${ }^{3}$ Embrapa Algodão, 58.107-720, Campina Grande, PB, Brazil

Author for correspondence: Ricardo M. Souza, e-mail: rmagelas@ufla.br

\begin{abstract}
Flow cytometric analysis of immuno-stained cells (immuno-FCM) was compared to immunofluorescence microscopy (IF) and dilution plating on a semi-selective medium, for quantitative detection of Xanthomonas axonopodis pv. phaseoli (Xap) in bean seed extracts. Cell concentrations of Xap between $10^{3}-10^{7} \mathrm{CFU} / \mathrm{mL}$ were added to healthy bean seed extracts. A flow cytometry sorting procedure was developed to separate immuno-stained Xap cells from crude seed extracts and confirming by PCR. FCM was evaluated for direct viable counting (DVC) of Xap using combinations of propidium iodide (PI) and carboxy fluorescein diacetate (cFDA) or PI and SYTO 9 and also the combination of immuno-FCM and PI. Dilution plating and IF allowed detection of Xap in bean seed extracts in a range of $10^{3}-10^{6} \mathrm{CFU} / \mathrm{mL}$ and immuno-FCM from $10^{4}-10^{6} \mathrm{CFU} / \mathrm{mL}$. Sorted cells could be detected in crude seed extracts by PCR without further extraction. FCM also allowed quantification of viable cells of Xap after DVC procedures; the red fluorescent dye propidium iodide was used to identify dead cells in combination with the green fluorescent dyes cFDA or SYTO 9, these identifying live cells. The combination of immuno-FCM and PI could be more promising and reliable to detect this pathogen in seeds.
\end{abstract}

Key words: seed pathology, flow sorting, PCR-amplification, viability probes, immunofluorescence, bacteria.

\section{RESUMO}

Detecção de Xanthomonas axonopodis pv. phaseoli em sementes de feijão usando citometria de fluxo em combinação com anticorpo e sondas fluorescentes de viabilidade

A combinação do uso do citômetro de fluxo (FCM) e de anticorpo policlonal (imuno-FCM) foi comparada à microscopia de imunofluorescência (IF) e ao plaqueamento em meio de cultura semi-seletivo, para a detecção de Xanthomonas axonopodis pv. phaseoli (Xap) em sementes de feijão. Concentrações de Xap variando de $10^{3}$ a $10^{7} \mathrm{CFU} / \mathrm{mL}$ foram adicionados aos extratos de sementes. Um método de separação pelo citômetro de fluxo foi desenvolvido para a detecção de Xap em extratos de semente e posterior confirmação por PCR. Para avaliação da viabilidade das células foram usadas sondas fluorescentes, iodeto de propídio (PI)/carboxi diacetato de fluoresceína (cFDA) e PI/SYTO 9 e também, a combinação de imuno-FCM e PI. Em meio semi-seletivo e IF foram detectadas $10^{3}-10^{6} \mathrm{UFC} / \mathrm{mL}$ e no FCM $10^{4}-10^{6} \mathrm{UFC} / \mathrm{mL}$, em extratos de sementes artificialmente infestados. Xap somente foi detectada em extratos de sementes por PCR, após o processo de separação pelo FCM. Foi possível pelo FCM a quantificação e identificação de células viáveis (verde fluorescente) e células mortas (vermelho fluorescente) de Xap, pelas sondas cFDA/SYTO 9 e PI, respectivamente. A combinação de immuno-FCM e PI poderá ser uma técnica promissora e segura para a detecção deste patógeno em sementes.

Palavras-chave: patologia de sementes, PCR, sondas de viabilidade, imuno-fluorescência, bactéria.

\section{INTRODUCTION}

Xanthomonas axonopodis pv. phaseoli (Smith) Vauterin, Hoste, Kersters \& Swinges (Xap) is a seedtransmitted plant-pathogenic bacterium which causes common blight of bean (Phaseolus vulgaris L.) (Saettler \& Perry, 1972). This disease causes major economic losses

Part of the Thesis of the first author. Universidade Federal de Lavras. Lavras MG. 2005. in commercial bean production worldwide, especially in tropical areas (Hall, 1994). To prevent common blight, disease-free seeds should be used. Therefore, testing of seed lots for the presence of the pathogen is the only efficient way to avoid spread of the disease.

Current routine methods for testing seed lots are plate assays or serological techniques. Plate assays consist of plating seeds or seed extracts on a semi-selective agar medium (Sheppard et al., 1989; Goszczynska \& Serfontein, 1998). This procedure is laborious and time consuming. Serological techniques include immunofluorescence (IF) 
cell-staining (Malin et al., 1983) and also enzyme-linked immunosorbent assay (ELISA) (Van Vuurde et al., 1983; Alvarez \& Lou, 1985). Neither method discriminates between viable and non-viable cells. The specificity of the reaction is highly dependent on the quality of the antibodies.

For detection and identification of Xap, PCRamplification methods have also been described (Audy et al., 1994; Toth et al., 1998). In general, PCR assays are rapid and highly specific, but quantification is difficult and amplification is prone to inhibition by contaminants present in seed samples (Van der Wolf \& Schoen, 2004).

Flow cytometry $(\mathrm{FCM})$ is a technique which allows high-speed multiparameter analysis and quantification of particles, such as bacterial cells. The analysis is based on size and granularity, and can be based on emission of fluorescent light, after staining with a fluorescent dye. FCM has already been used in combination with antibody staining (immunoFCM) for the detection of Clavibacter michiganensis subsp. michiganensis (Smith) Davis, Gillaspie, Vidaver \& Harris in tomato seed extracts, and Xanthomonas campestris pv. campestris (Pammel) Dowson in cabbage seed extracts (Chitarra et al., 2006). In theory, FCM can replace visual observation and quantification of bacteria in IF cell-staining (Diaper \& Edwards, 1994; Bunthof et al., 2001).

FCM can also be used to analyze bacterial cells after direct viable count staining (DVC), by using fluorescent probes distinguishing viable from non-viable cells. Currently, different fluorescent probes are available for DVC, targeting various processes, including enzyme activity, respiration, $\mathrm{pH}$ gradient, membrane potential and the integrity of the cell membrane (Rechinger \& Siegumfeldt, 2002). In contrast to plating techniques, DVC methods allow the detection of cells in a viable but non culturable state (VBNC). Cells in a VBNC state have already been found for the taxonomically related $X$. campestris pv. campestris in sterile soil (Ghezzi \& Steck, 1999) and may also exist for Xap.

The combination of FCM and DVC methods with fluorescent probes has been used for the detection of bacteria in water (Lebaron et al., 1998), food (Gunasekera et al., 2000) and phytopathogenic bacteria such as $C$. michiganensis subsp. michiganenis and $X$. campestris pv. campestris (Chitarra et al., 2006). The aim of this work was to evaluate FCM methods for the detection and quantification of Xap in crude bean seed extracts and to compare with IF and dilution plating; to evaluate different fluorescent probes for direct viable count staining of Xap and to develop a FCM sorting method for PCR amplification directly on sorted sample fluid, without the need of DNA purification.

\section{MATERIAL AND METHODS}

\section{Seed lots}

Two Xap-free (cvs. Carioca and Perola) and three naturally infected bean seed lots (cvs. Roxo, Valente and Vermelho) were used. They were produced in the States of Minas Gerais and Santa Catarina, respectively, in Brazil.
Additionally one Xap-free seed lot (cv. Nuria) produced in the Netherlands was used. The contamination level of the seed lots was determined based on plate count results.

\section{Bacterial strain and growth conditions}

Xap 510 (NCPPB 1811) isolated from bean was grown on medium 523 (Kado \& Heskett, 1970) for $48 \mathrm{~h}$ at $28^{\circ} \mathrm{C}$. Cells were resuspended in phosphate buffered saline (PBS) $\left(8 \mathrm{~g}\right.$ of $\mathrm{NaCl}, 2.7 \mathrm{~g}$ of $\mathrm{Na}_{2} \mathrm{HPO}_{4} \cdot 12 \mathrm{H}_{2} \mathrm{O}$, and $0.4 \mathrm{~g}$ of $\mathrm{NaH}_{2} \mathrm{PO}_{4} \cdot 2 \mathrm{H}_{2} \mathrm{O}$, per liter, $\mathrm{pH}$ 7.2) prior to use in the artificially contaminated seed extract. For experiments on direct viable counting, Xap was grown to the exponential phase in Nutrient Broth (Oxoid, England) at $28^{\circ} \mathrm{C}$ for 24 $\mathrm{h}$, while shaking at $250 \mathrm{rpm}$. Cells were centrifuged at $10,000 \mathrm{~g}$ for $3 \mathrm{~min}$ and washed twice in 0.01 M PBS or in $0.85 \%(\mathrm{w} / \mathrm{v}) \mathrm{NaCl}$. Cells were resuspended either in PBS for staining with carboxy fluorescein diacetate (cFDA) or in $0.85 \%(\mathrm{w} / \mathrm{v}) \mathrm{NaCl}$ for staining with SYTO 9. The optical density was measured with a spectrophotometer at $600 \mathrm{~nm}$ and adjusted by diluting with $\mathrm{PBS}$ or $\mathrm{NaCl}$ to approximately 0.14 in order to obtain a suspension of $5 \times 10^{7} \mathrm{CFU} / \mathrm{mL}$.

\section{Immuno-FCM}

The polyclonal antibody Xcph 103 (Plant Research International) was purified using protein $\mathrm{G}$ sepharose fast flow (Amersham Biosciences, 2002). Crude serum was diluted one time with $40 \mathrm{mM}$ sodium phosphate $\mathrm{pH} 7.0$ and passed through a $0.2 \mu \mathrm{m}$ filter. The protein G sepharose instructions were followed using $40 \mathrm{mM}$ sodium phosphate $\mathrm{pH} 7.0$ as a binding buffer and $0.1 \mathrm{M}$ glycine- $\mathrm{HCl} \mathrm{pH} 2.7$ as elution buffer. Eluted $\operatorname{IgG}$ fractions were pooled and buffer exchanged to PBS using PD-10 columns (Amersham Biosciences, 2002), resulting in an IgG fraction of $6 \mathrm{mg} /$ $\mathrm{mL}$. The antibodies were labeled with Alexa $488\left(\lambda_{\text {ex }} 488\right.$ $\mathrm{nm}, \lambda_{\mathrm{em}} 519 \mathrm{~nm}$ ) (Invitrogen, Breda, the Netherlands) and purified form free dyes according to protocol. For FCM, the optimal dilution of the antibody was determined at 1:100.

In an artificially contaminated seed extract, a pure culture of Xap was diluted in PBS to concentrations between $5 \times 10^{7}$ and $5 \times 10^{3} \mathrm{CFU} / \mathrm{mL}$. For this, $50 \mu \mathrm{L}$ of each Xap concentration was added to $450 \mu \mathrm{L}$ of a 10 or 100 times diluted seed extract. Naturally infected seed extracts were also diluted 10 or 100 times before staining. Samples $(500 \mu \mathrm{L})$ were stained by incubation with $20 \mu \mathrm{L}$ pre-immune serum and $5 \mu \mathrm{L}$ Alexa 488-conjugated antibodies at room temperature for $20 \mathrm{~min}$ in the dark. Cells were spun down at 16,000 $\mathrm{g}$ for 5 minutes, washed, resuspended in PBS and analyzed by FCM.

\section{Dilution plating}

Seeds extracts were incubated in sterilized tap water (100 seeds in $60 \mathrm{~mL}$ of sterilized tap water) overnight at $4^{\circ} \mathrm{C}$. Subsequently, ten-fold serial dilutions were made from each seed extract. Of each dilution $100 \mu \mathrm{L}$ was plated in triplicate on semi-selective medium XCP1 (10 g of Oxoid peptone, $10 \mathrm{~g}$ of $\mathrm{KBr}, 0.25 \mathrm{~g}$ of $\mathrm{CaCl}, 10 \mathrm{~g}$ of soluble potato starch, $0.15 \mathrm{~mL}$ of crystal violet, $15 \mathrm{~g}$ of bacto agar, 
per liter, after sterilizing add $50 \mathrm{mg} / \mathrm{L}$ of cephalexin, 10 $\mathrm{mg} / \mathrm{L}$ of 5 -fluorouracil, $0.4 \mathrm{mg} / \mathrm{L}$ of cycloheximide and $10 \mathrm{~mL}$ of Tween 80 ). After incubation for 72 or 96 hours at $28^{\circ} \mathrm{C}$, the number of $\mathrm{CFU} / \mathrm{mL}$ of suspected colonies was determined. For viability studies, ten-fold serial dilutions of pure culture samples were prepared in 0.01 M PBS (pH 7.2) and triplicate aliquots of $100 \mu \mathrm{L}$ of the dilutions were plated on 523 medium, to determine the number of culturable cells. The colonies were counted 48 $\mathrm{h}$ after incubation at $28^{\circ} \mathrm{C}$.

\section{Fluorescence microscopy}

To detect bacteria in seed extracts, three replicates of the 10-fold diluted seed extract were spread on a microscope slide. Subsequently, samples were incubated with primary antibody Xcph 103 (dilution 1:900) and secondary goat-anti rabbit antibodies conjugated with fluorescein isothiocyanate (FITC) (Sigma) (dilution $1: 40$ ) and the number of positive cells was determined. The bacterium suspensions after direct viable counting were immobilized on a glass surface, which was coated with $20 \mu \mathrm{L}$ of a poly-L-lysine solution $(0.1 \mathrm{mg} / \mathrm{mL}$, $100.000 \mathrm{MW}$ ) by incubating slides for $10 \mathrm{~min}$ at room temperature. Subsequently, glasses were dried with paper and $5 \mu \mathrm{L}$ of stained cells were added and covered with an $18 \mathrm{~mm}$ square slip and observed under a fluorescence microscope (Leitz, Laborlux D). Labeled cells were visualized when agitated by the blue light ( $495 \mathrm{~nm})$, using a 100x objective magnification, 10x ocular magnification. Photomicrographs were taken with a digital camera (Leica DFC 320, Software Leica IM500).

\section{Flow cytometric analysis}

Flow cytometry was performed with a Coulter EPICS XL-MCL flow cytometer (Beckman-Coulter Electronics, Epics XL MCL) equipped with a $15 \mathrm{~mW}$ Argon ion laser at $488 \mathrm{~nm}$. A band pass filter of $530 \mathrm{~nm}(515$ to $545 \mathrm{~nm})$ was used to collect the green fluorescence (FL1) and a band pass filter of $585 \mathrm{~nm}$ (564 to $606 \mathrm{~nm}$ ) was used to collect the red fluorescence (FL3).

In seed extracts, cells were separated from the background on the basis of their side and forward scatter characteristics. Green fluorescence emission was measured with antibody labeling with Alexa 488. For direct viable staining, green fluorescence emission (FL1) was measured for cFDA and SYTO 9 and red fluorescence emission (FL3) for PI. For combined immunostaining and DVC staining with PI, the green fluorescence was measured by FL1 and the red fluorescence was measured by FL3. The density of labeled cells present in each sample was calculated based on the number of events and volume $(\mu \mathrm{L})$ of the suspension analyzed per second. Four subsamples of three bean seed lots naturally infected with Xap (Roxo, Valente, Vermelho) were analyzed in four independent experiments by immunoFCM, dilution plating on semi selective medium (XCP1) and IF-microscopy.

\section{FCM-sorting of the seed extract}

Immuno-FCM was used in combination with cell sorting to isolate Xap from seed extracts, in order to improve detection of Xap by PCR and dilution plating. Cell sorting was done on samples of naturally-infected and Xapfree seed extracts, stained with 100-fold diluted Alexa 488conjugated antibodies, in the presence of 25 fold-diluted pre-immune serum, at room temperature for 20 minutes in the dark. Cells were sorted by a hypersorter (Beckman Coulter, Epics Altra) based on the green fluorescence of the cells at $530 \mathrm{~nm}$. Cells were counted by flow cytometry. From the samples before and after sorting $10 \mu \mathrm{L}$ was analyzed by PCR and $50 \mu \mathrm{L}$ by plating on medium 523 . Approximately $10^{5}$ cells were sorted per sample. The identity of suspected colonies on medium 523 was confirmed by PCR.

\section{PCR-amplification}

PCR assays were performed in a $50 \mu \mathrm{L}$ reaction mixture containing: $1 \mu \mathrm{L}$ bacteria cell suspension, 1 $\mathrm{X}$ reaction buffer (Life Technologies), 1 U Taq DNA polymerase, $0.3 \mu \mathrm{mol} / \mathrm{L}$ of each primer X4c (5'GGCAACACCCGATCCCTAAAACAGC-3') and X4e (5'-CGCCGGAAGCACGATCCTCGAAG-3'), 100 $\mu \mathrm{mol} / \mathrm{L}$ of each dNTPs and $0.75 \mathrm{mmol} / \mathrm{L} \mathrm{MgCl}_{2}$ (Toth et al., 1998). PCR amplification was performed in a thermocycler (Perkin Elmer, Applied Biosystems 9600, Norwalk, USA) under the following conditions: 37 cycles at $94^{\circ} \mathrm{C}$ for $30 \mathrm{~s}, 65^{\circ} \mathrm{C}$ for $30 \mathrm{~s}$ and $72^{\circ} \mathrm{C}$ for $1 \mathrm{~min}$, with a final extension of $72^{\circ} \mathrm{C}$ for $10 \mathrm{~min}$. The amplified product was analyzed by gel electrophoresis on a $1 \%(\mathrm{w} /$ v) agarose gel and visualized by staining with ethidium bromide.

\section{Direct viable counting}

Two direct viable staining procedures were evaluated based on the use of fluorescent probes. In the first cFDA and PI were used, and in the second SYTO 9 and PI. Bacterial suspensions were heat-treated in a water bath at $90^{\circ} \mathrm{C}$ for $20 \mathrm{~min}$ to kill cells. After the treatment, dead cells were no longer culturable on medium 523. Non-treated and heat-treated bacterial cells were mixed such that populations were obtained with $100,80,50,20$ and $0 \%$ viable cells. Bacterium was fixed with glutaraldehyde (GTA) and labeled with cFDA $\left(\lambda_{\text {ex }} 492 \mathrm{~nm}, \lambda_{\text {em }} 517 \mathrm{~nm}\right)$ (Invitrogen, Breda, the Netherlands), according to the protocol described by Morono et al. (2004). Cells were also labeled with propidium iodide (PI) $\left(\lambda_{\mathrm{ex}} 535 \mathrm{~nm}, \lambda_{\mathrm{em}} 617 \mathrm{~nm}\right)$, which enter bacterial cells only if membranes are damaged.

Double staining with cFDA and PI was performed using $50 \mu \mathrm{L}$ of the cell suspension, $950 \mu \mathrm{L}$ of PBS with a final concentration of $0.1 \mathrm{mM} \mathrm{GTA}, 5 \mu \mathrm{L}$ of the stock solution of cFDA ( $1 \mathrm{mM}$ in anhydrous dimethylsulfoxide) and $10 \mu \mathrm{M}$ of PI (final concentration). Samples were incubated for $15 \mathrm{~min}$ at room temperature. Subsequently, the cells were centrifuged at $11,000 \mathrm{~g}$, washed and 
resuspended in $0.01 \mathrm{M} \mathrm{PBS} \mathrm{pH} \mathrm{7.2.} \mathrm{Cell} \mathrm{suspensions} \mathrm{were}$ also double labeled with SYTO 9 in combination with PI, using the Live/ Dead BacLight Bacterial Viability Kit (Invitrogen, Breda, Netherlands). SYTO $9\left(\lambda_{\text {ex }} 485\right.$ $\mathrm{nm}, \lambda_{\text {em }} 498 \mathrm{~nm}$ ) can permeate intact cell membranes. Once inside the cell, it binds to nucleic acids. SYTO 9 and PI were used in a final concentration of $5 \mu \mathrm{M}$ and $30 \mu \mathrm{M}$, respectively, in $990 \mu \mathrm{L}$ of $0.85 \% \mathrm{NaCl}$ and 10 $\mu \mathrm{L}$ of cell suspension, according to the manufacturer's instructions. Samples varying in the percentage of viable cells and heat-killed cells were stained and analyzed by FCM and fluorescence microscopy.

\section{Immunostaining in combination with direct viable staining}

Samples of Xap pure culture were prepared varying the percentage of viable cells, by mixing live and heat-killed cells $(100,80,50,20$ and $0 \%$ of viable cells); they were then 10 -fold diluted with PBS and plated in medium 523. The suspensions were stained with 100fold diluted antibodies conjugated with Alexa 488 (green fluorescence) and $10 \mu \mathrm{M}$ of PI (red fluorescence) and incubated for $20 \mathrm{~min}$ in the dark. Samples were analyzed by FCM and fluorescence microscopy.

\section{RESULTS}

\section{Comparison of immuno-FCM, dilution plating and IF- microscopy}

Alinear relation was found between the concentrations of Xap added to the seed extracts, and the number of cells counted by IF and immuno-FCM. The dynamic range for dilution plating and IF was between $10^{3}$ and $10^{6} \mathrm{CFU} / \mathrm{mL}$, and for immuno-FCM between $10^{4}$ and $10^{6} \mathrm{CFU} / \mathrm{mL}$ (Figure 1). In undiluted seed extracts, the Xap could not be detected due to a high background (results not shown). FCM analysis could only detect Xap in bean seed extracts after addition of pre-immune serum, which blocked non-specific reactions of antibodies and reduced the background (Figure 2), and the detection level was $10^{4} \mathrm{CFU} / \mathrm{mL}$.

Immuno-FCM detected Xap in all four subsamples at a density of $10^{6}-10^{7} \mathrm{CFU} / \mathrm{mL}$ (Figure 3). Densities of Xap determined by IF in cv. Roxo and cv. Valente were similar to those in immuno-FCM, but in cv. Vermelho densities were lower in three out of four subsamples. Xap was detected by dilution plating in all subsamples except in sample $3 \mathrm{of} \mathrm{cv}$. Valente and sample 2 and $4 \mathrm{of} \mathrm{cv}$. Vermelho. The number of CFU/mL determined by dilution plating was often lower than that determined by IF and immuno-FCM. From two subsamples of three supposedly healthy seed lots

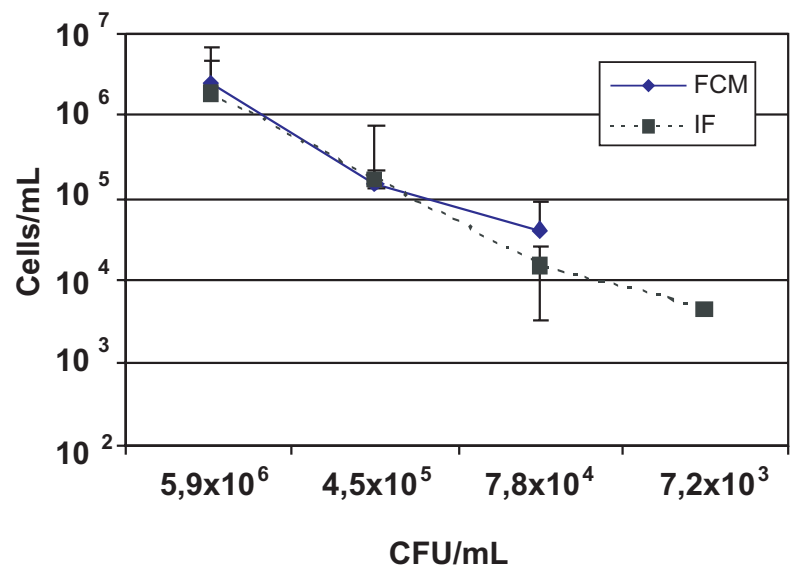

FIGURE 1 - Detection of Xanthomonas axonopodis pv. phaseoli added to bean seed extracts by immuno-flow cytometry (FCM) and immunofluorescence microscopy (IF). Cell densities (CFU/ $\mathrm{mL}$ ) were determined by dilution plating on XCP1 medium.

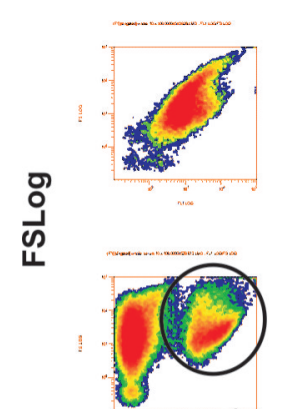

(1,2×10 $\mathrm{CFU} / \mathrm{mL})$

$10^{6}$

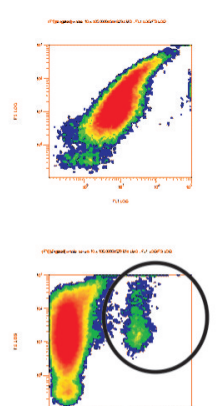

$\left(1,6 \times 10^{5} \mathrm{CFU} / \mathrm{mL}\right)$

$10^{5}$
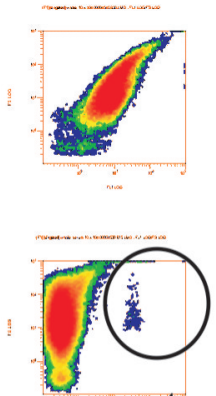

(5.,0x10 $\left.{ }^{4} \mathrm{CFU} / \mathrm{mL}\right)$

$10^{4}$
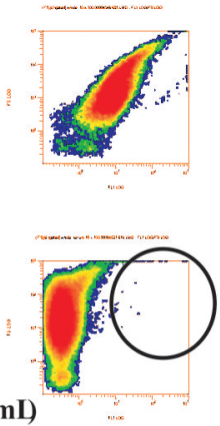

$10^{3}$

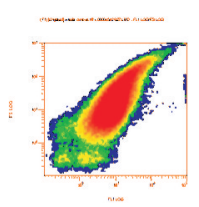

A

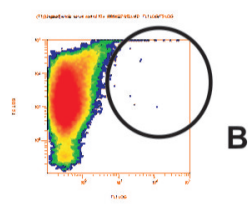

o (CFU/mL)

FL1

FIGURE 2 - Immuno-FCM density plots of ten-fold serial dilutions $\left(10^{6}, 10^{5}, 10^{4}, 10^{3} \mathrm{CFU} / \mathrm{mL}\right)$ of Xanthomonas axonopodis pv. phaseoli in a ten-fold diluted artificially contaminated seed extract. A) No pre-immune serum added. B) Pre-immune serum added as a blocking agent. The green fluorescent particles are indicated with a circle. Between brackets, the number of green fluorescent particles is given. FL1 = green fluorescence, FS = forward scattering. 
of cultivars Carioca, Perola and Nuria, Xap was detected by dilution plating in only one subsample of $\mathrm{cv}$. Carioca in a low density of $10^{2} \mathrm{CFU} / \mathrm{mL}$. In immuno-FCM and IFmicroscopy, relatively high densities of fluorescent cells $\left(10^{5} \mathrm{CFU} / \mathrm{mL}\right)$ were found in both subsamples of cultivars Carioca, Perola and Nuria.

\section{FCM-sorting and PCR}

Prior to sorting, Xap was detected by plating in all samples, except in the cv. Carioca, but Xap could not be detected in the crude seed extracts by PCR (Table 1). After sorting, Xap was detected by PCR and by plating in all samples analyzed, except in the supposed Xap-free seed lot cv. Perola. Xap was also detected in the sorted fluids on plates, although cell numbers were low and saprophytic bacteria were still present (data not shown).

\section{Direct viable counting}

In the fluorescence microscopy with both dual staining procedures, in samples with $100 \%$ of viable cells most were green and only a few were red (Figure 4A and D). In samples with $50 \%$ of viable cells, $50 \%$ of the cells were green and $50 \%$ were red (Figure $4 \mathrm{~B}$ and $\mathrm{E}$ ). In samples with $0 \%$ of viable cells, all cells were red (Figure $4 \mathrm{C}$ and F). The Figure 4G, H and I shows viable cells stained only with cFDA or SYTO9 and dead cells only with PI, respectively. In the FCM analysis the viable cells (green fluorescence) were identified by FL1 and the dead (red fluorescence) by FL3. A linear relation $\left(\mathrm{R}^{2} \geq\right.$ 0.97 ) was found between the percentage of viable (green fluorescent) and heat-killed cells (red fluorescent), both after dual staining with cFDA and PI and with SYTO 9 and PI (Figure 5).

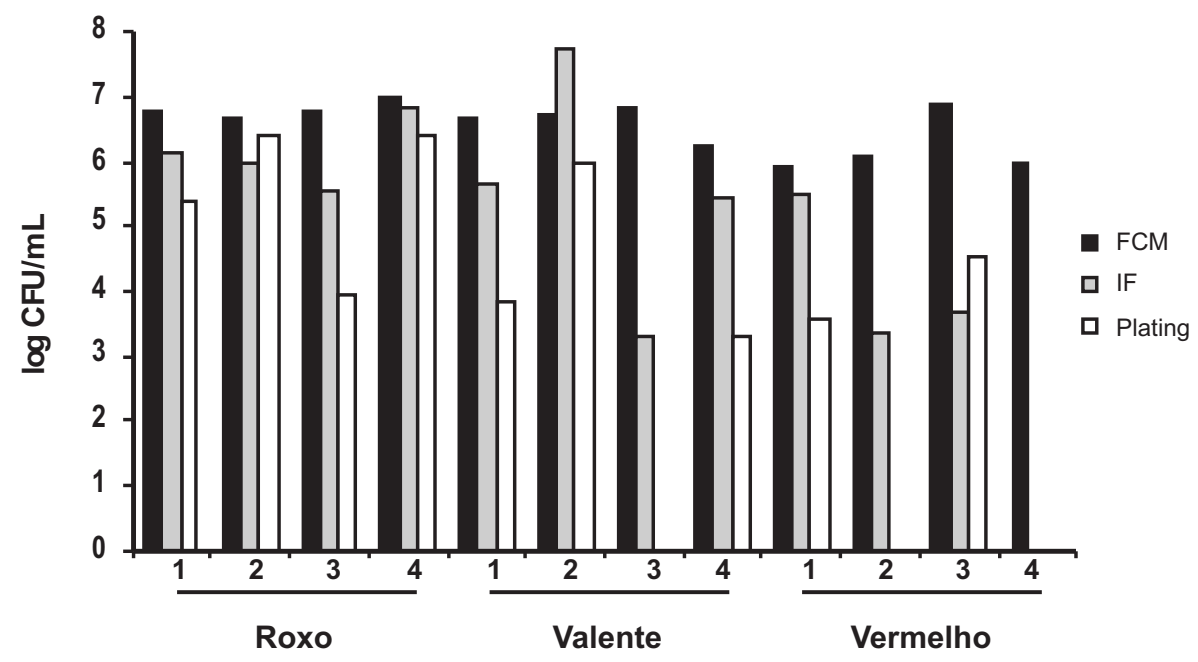

FIGURE 3 - Detection of Xanthomonas axonopodis pv. phaseoli in naturally infected seed lots of the cultivars Roxo, Valente and Vermelho, by immuno-flow cytometry (FCM), immunofluorescence microscopy (IF) and dilution plating. Four different subsamples of each seed lot were tested independently.

TABLE 1 - Detection of Xanthomonas axonopodis pv. phaseoli (Xap) in bean seed extracts by PCR and dilution plating on medium 523, before and after sorting

\begin{tabular}{lcccc}
\hline \hline Cultivar & \multicolumn{2}{c}{ Before Sorting } & \multicolumn{2}{c}{ After Sorting } \\
\cline { 2 - 5 } & PCR $^{\mathbf{1}}$ & Medium $^{2}$ & PCR $^{\mathbf{1}}$ & ND \\
\hline Carioca & - & - & ND & + \\
Nuria & - & + & + & + \\
Perola & - & + & + & + \\
Roxo & - & + & + & + \\
Valente & - & + & + & + \\
Vermelho & - & + & + & + \\
Xap & + & + & + & + \\
Carioca + Xap & ND & + & + \\
\hline
\end{tabular}




\section{Immunostaining in combination with direct viable counting}

Immuno-FCM could distinguish two clusters in $100 \%$ of viable cells, a cluster of green fluorescent particles (A) and a small cluster of particles emitting both green and red fluorescence (B) (Figure 6). In $80 \%$ of viable cells, cluster B increased in size. In $50 \%$ and $20 \%$ of live cells, a third cluster $(\mathrm{C})$ appeared of red particles with a low level of green fluorescence (A). In samples containing heat-killed cells with $0 \%$ viable cells, only red fluorescent particles in cluster (C) were detected. Fluorescence microscopy distinguished viable (green) and dead (red) cells (Figure 7).
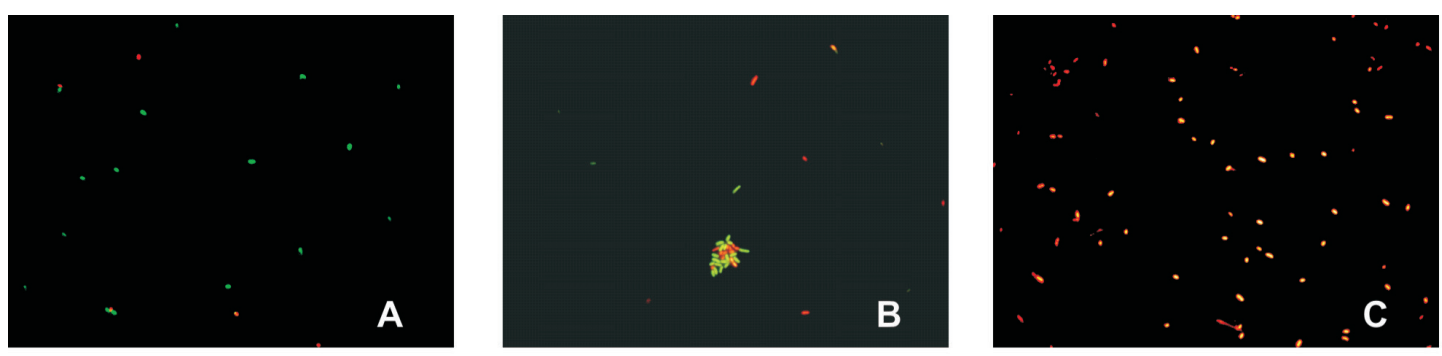

cFDA/PI
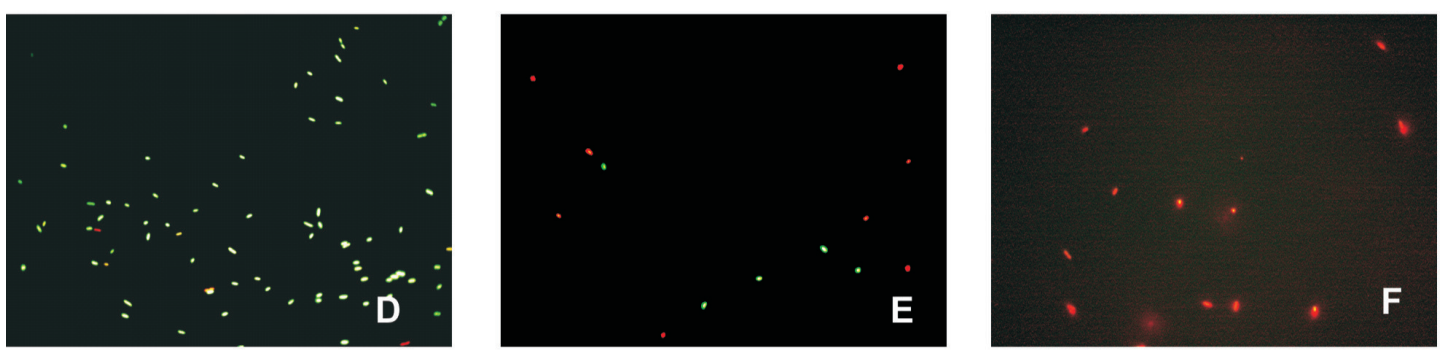

Syto9/PI
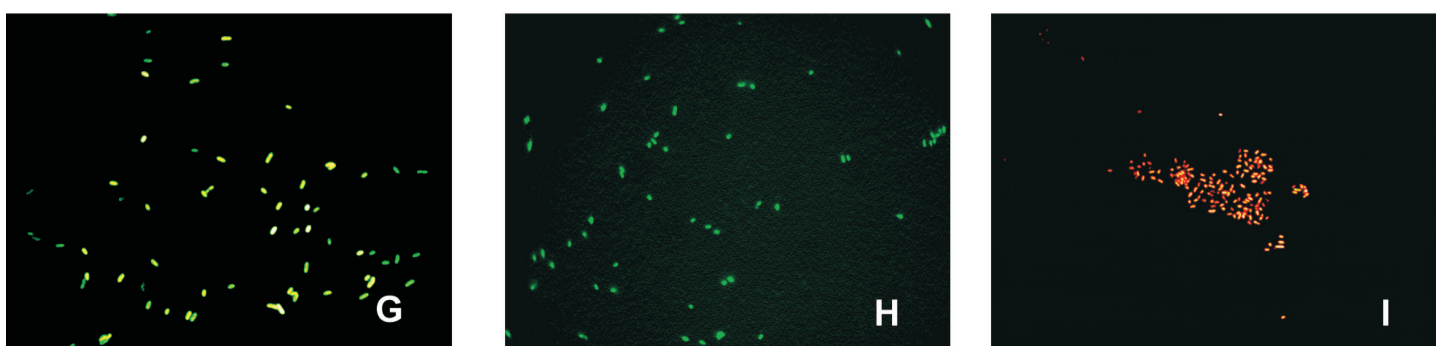

FIGURE 4 - Photomicrographs of mixtures of viable and heat-killed cells of Xanthomonas axonopodis pv. phaseoli stained with fluorescent probes. Suspensions contained 100\% (A, D), 50\% (B, E) and $0 \%$ (C, F) of viable cells double stained with carboxyfluorescein diacetate (cFDA) and propidium iodide (PI) or with SYTO9 and PI, respectively. Viable cells were also stained only with cFDA $(\mathrm{G})$ or SYTO9 $(\mathrm{H})$, and dead cells only with PI (I). Cells were visualized by fluorescence microscopy using blue light for excitation.
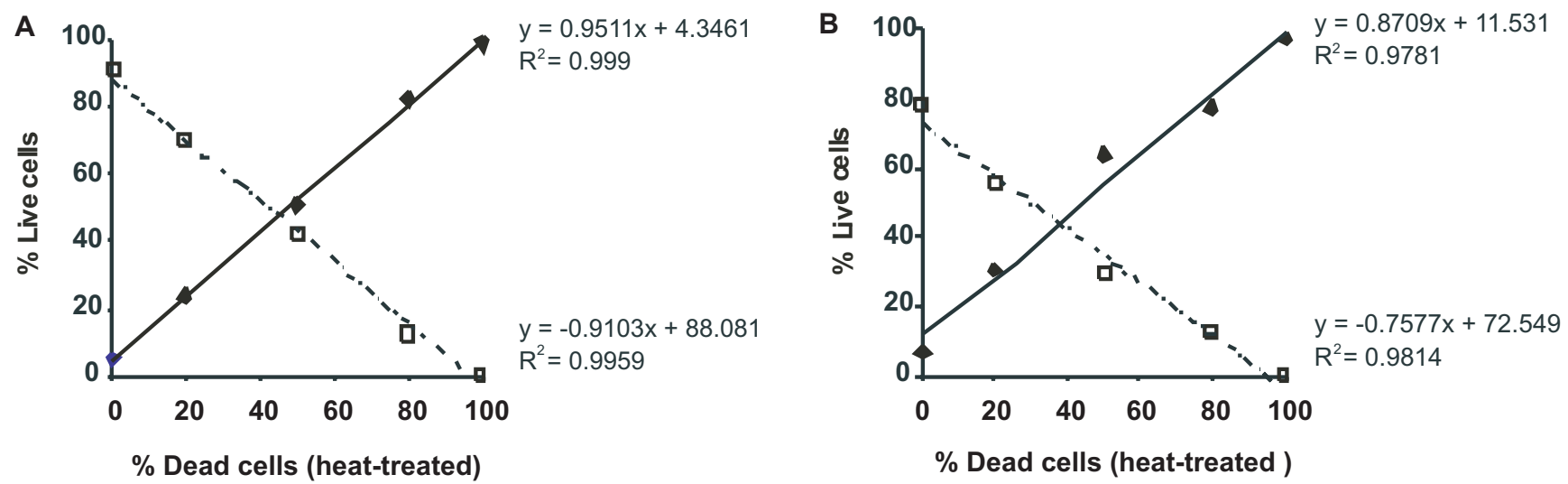

FIGURE 5 - Linear relation between ratios of viable and dead (heat-treated) cells and the number of fluorescent particles after dual staining with cFDA and PI (A) or Syto 9 and PI (B) for pure culture of Xanthomonas axonopodis pv. phaseoli as estimated by flow cytometry. ( $\downarrow=$ red cells $(\%)$ and $\square=$ green cells $(\%)$ ). 


\section{DISCUSSION}

Immuno-FCM allowed rapid quantification of Xap in bean seed extracts. The procedure included a short incubation with antibodies and it could be completed within one hour. It was faster and less time consuming than IF, in which visual observations are less objective and can be tiresome and laborious.

The detection limit of immuno-FCM in a ten-fold diluted bean extract was ca. $10^{4}$ and the dynamic range was from $10^{4}$ to $10^{6}$ cells per $\mathrm{mL}$. Similar results have been found for detection of Salmonella typhimurium in eggs and milk with immuno-FCM (McClelland \& Pinder,
1994; Gunasekera et al., 2000). The detection level of immunofluorescence microscopy (IF) was ten times lower, whereas dilution plating was even more sensitive. Although the use of pre-immune rabbit serum considerably reduced non-specific binding of antibodies to sample particles, still a certain level of auto-fluorescent particles remained present, which was responsible for a relatively high background in immuno-FCM.

In naturally-infected seed lots, Xap was detected in most of them by immuno-FCM, IF and dilution plating. The absence of CFU on the semi-selective medium in some subsamples of Valente and Vermelho cultivars may be explained by the presence of non-culturable cells,

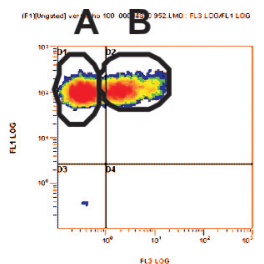

100

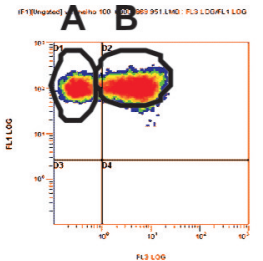

80

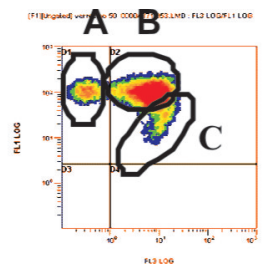

50

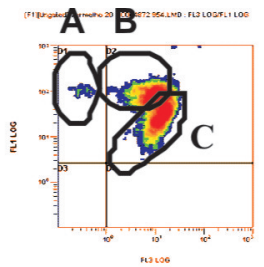

20

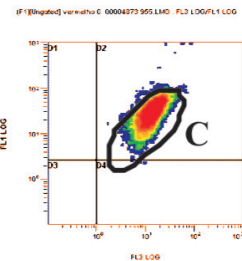

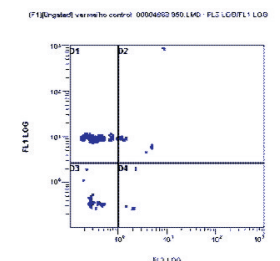

0 Control

$\%$ Live cells

FIGURE 6 - Flow cytometry density plots of green fluorescent and red fluorescent particles, after staining different percentages of live and dead cells of Xanthomonas axonopodis pv. phaseoli with antibodies conjugated with Alexa 488 (green fluorescence) and propidium iodide (red fluorescence). A) Cluster of green fluorescent particles. B) Cluster of green and red fluorescent particles. C) Cluster of red fluorescent particles. Control, cells in PBS.

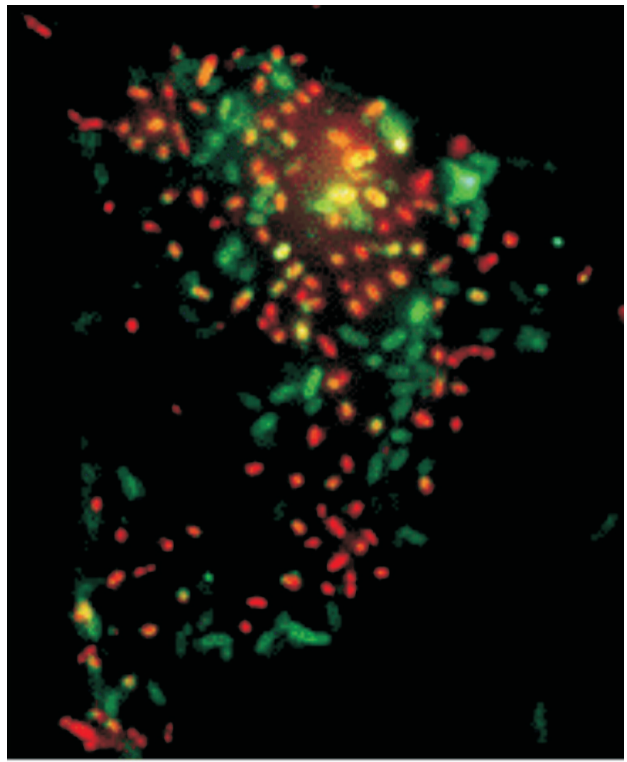

FIGURE 7 - Mixture of $50 \%$ of live and dead cells, simultaneously stained with antibodies conjugated with Alexa 488 and with propidium iodide. Live cells are green and dead cells red. 
which may be dead or in a viable but non-culturable (VBNC) state. According to Gehzzi \& Steck (1999) X. campestris pv. campestris is able to enter the VBNC state. Conditions that can induce non-culturability differ depending on the organism and include various factors, such as starvation, water stress, salinity, visible light and temperature (McDougald et al., 1998). Cells are able to exit the VBNC state and return to an actively metabolizing state when conditions become favorable for the pathogen (McDougald et al., 1998). If Xap are present in a VBNC state in the seed extract, dilution plating will underestimate the actual number of cells, potentially able to cause blight on beans. The dry and cool conditions in which seeds are stored for long periods may induce nonculturability, although Xap has been isolated by dilution plating from seed stored for 15 years at $10^{\circ} \mathrm{C}$ (Neergaard, 1979).

The densities estimated in immuno-FCM and IF were largely similar for 8 out of 12 subsamples. For four subsamples higher densities were found in immuno-FCM. This discrepancy may be explained by the high sensitivity of the laser-based flow cytometric measurement. A weak fluorescence caused by low numbers of molecules of the fluorochrome (e.g. $<1000$ FITC molecules per particle) is detected already. Cross-reactions or non-specific bindings may therefore result in false-positive reactions in FCM (Clarke \& Pinder, 1998). For several plant-pathogenic bacteria cross-reactions with saprophytic bacteria have been described (Franken et al., 1992). Therefore, the use of antibodies with a higher specificity, such as monoclonal antibodies, is desirable in immuno-FCM.

Also in the supposed pathogen-free seed lots (typical) fluorescent cells were detected by IF and immuno-FCM. In contrast, in two subsamples tested from three seed lots, only in one subsample of cv. Carioca a few colonies were found on plates. In the FCMsorting experiments, however, Xap was also found in low densities in a subsample of cv. Nuria and cv. Perola. It can be concluded that these supposedly Xap-free samples contained low levels of culturable cells, which makes it more likely that at least part of the fluorescent cells found at $10^{5} \mathrm{CFU} / \mathrm{mL}$ by IF and immuno-FCM in cv. Perola and cv. Nuria are non-culturable cells of Xap.

The potential of flow sorting was explored for isolation from bean extracts to enhance detection of Xap by PCR or dilution plating. Xap could not be detected directly in crude seed extracts by PCR due to the presence of inhibitors. After sorting, Xap could be detected directly in the sampled sorting fluid, indicating that PCR-inhibiting compounds were largely removed. The sorting procedure, however, could be optimized further, as dilution plating on a non-selective agar medium showed that during the sorting procedure other bacteria had also been sorted.

Two DVC methods were evaluated and found suitable to distinguish viable from dead cells of Xap, a dual staining method with cFDA and PI, and with SYTO 9 and PI. DVC methods on the basis of dual staining with cFDA and PI have been described for other bacterial species (Bunthof et al., 2001; Ben Amor et al., 2002; Hoefel et. 2003a-b, Chitarra et al., 2006). cFDA, which is an esterified fluorogenic substrate assessing bacterium esterase activity, was able to stain specifically viable cells of Xap. In line with Morono et al. (2004), it was found that the use of glutaraldehyde prevented the leakage of $\mathrm{cF}$ out of the cell, improving the efficacy to discriminate viable from dead cells (results not shown). PI specifically stained dead cells of Xap. PI is membrane impermeable and only stains dead bacteria with damaged membranes (Haugland, 2002).

PI is also used in the LIVE/DEAD bacterial viability kit in combination with SYTO 9, which is a green fluorescent, membrane permeable nucleic acid stain, which stains bacteria irrespective of their viability. PI and SYTO 9 have been used for the direct enumeration of physiologically active bacteria in drinking water (Boulos et al., 1999) and also in other fields of bacteriological research (Lebaron et al., 1998; Auty et al., 2001). For DVC of Xap, the use of cFDA and PI is preferred over the use of PI and SYTO 9, because cFDA in contrast to SYTO 9 is able to discriminate viable from non-viable cells. Samples need to be measured immediately after staining cells with SYTO 9/PI, to avoid an increase in dead red fluorescent cells. In particular, SYTO 9 was toxic to Xap. The number of non-staining cells decreased from $1.7 \times 10^{7} \mathrm{CFU} / \mathrm{mL}$ to $1 \times 10^{6} \mathrm{CFU} / \mathrm{mL}$ after staining with SYTO 9/PI plated on medium 523.

Studies on DVC methods should preferably be done with liquid media rather than solid agar media. The bacterial suspensions from liquid growth medium contain a higher percentage of culturable cells than an agar medium (data not shown). Possibly, cells were stressed on agar plates or died from limited nutrients and the build-up of toxic products (Clarke \& Pinder, 1998). The combination of immuno-FCM and DVC techniques was evaluated to distinguish live and dead cells of Xap. This would also allow use of immuno-FCM after seed treatments carried out to eliminate seed-borne pathogens, such as heat treatments. This dual staining method was able to distinguish viable from dead cells in pure cultures, but not in seed extract, due to a high background of red fluorescent particles.

\section{ACKNOWLEDGEMENTS}

Financial support was provided by Coordenação de Aperfeiçoamento de Pessoal de Nível Superior - CAPES (BEX 1382039) and Fundação de Amparo à Pesquisa do Estado de Minas Gerais - FAPEMIG from Brazil. We are grateful to Dr. Murilo Lobo Junior (EMBRAPA Arroz e Feijão, CNPAF, Brazil) and Dr. Joice Aparecida Marques Santos (EMBRAPA, CNPMS, Brazil) for providing naturally infected and pathogen-free bean seeds, respectively. 
Detection of Xanthomonas axonopodis pv. phaseoli in bean seeds by flow cytometry...

\section{REFERENCES}

Alvarez AM, Lou K (1985) Rapid identification of Xanthomonas campestris pv. campestris by ELISA. Plant Disease 69:10821086 .

Amersham Biosciences (2002) Protein G Sepharose 4 fast. In: Antibody Purification Handbook. Life Science News 12.

Audy P, Laroche A, Saindon G, Huang HC, Gilbertson RL (1994) Detection of the bean common blight bacteria, Xanthomonas campestris pv. phaseoli and X. c. phaseoli var. fuscans, using the polymerase chain reaction. Phytopathology 84:1185-1192.

Auty MAE, Gardiner GE, Mcbrearty SJ, O'Sullivan EO, Mulvihill DM, Collins JK, Fitzgerald GF, Station C, Ross RP (2001) Direct in situ viability assessment of bacteria in probiotic dairy products using viability staining in conjunction with confocal scanning laser microscopy. Applied and Environmental Microbiology 67:420-425.

Ben Amor K, Breeuwer P, Verbaarschot P, Rombouts FM, Akkermans ADL, De Vos, WM, Abee T (2002) Multiparametric flow cytometry and cell sorting for the assessment of viable, injured, and dead Bifidobacterium cells during bile salt stress. Applied and Environmental Microbiology 68:5209-5216.

Boulos L, Prévost M, Barbeau B, Coallier J, Desjardins R (1999) Live/Dead ${ }^{\circledR}$ Baclight $^{\mathrm{TM}}$ : application of a new rapid staining method for direct enumeration of viable and total bacteria in drinking water. Journal of Microbiological Methods 37:77-86.

Bunthof CJ, Bloemen K, Breeuwer P, Rombouts FM, Abee T (2001) Flow cytometric assessment of viability of lactic acid bacteria. Applied and Environmental Microbiology 67:23262335 .

Chitarra LG, Breeuwer P, Abee T, Van Den Bulk RW (2006) The use of fluorescent probe to assess viability of the plant pathogenic bacterium Clavibacter michiganensis subsp. michiganensis by flow cytometry. Fitopatologia Brasileira 31:349-356.

Clarke RG, Pinder AC (1998) Improved detection of bacteria by flow cytometry using a combination of antibody and viability markers. Journal of Applied Microbiology 84:577-584.

Diaper JP, Edwards C (1994) The use of fluorogenic esters to detect viable bacteria by flow cytometry. Journal of Applied Bacteriology 77:221-228.

Franken AALM, Zilverentant JF, Boonekamp PM, Schots A (1992) Specificity of polyclonal and monoclonal antibodies for the identification of Xanthomonas campestris pv. campestris. Netherlands Journal of Plant Pathology 98:81-94.

Ghezzi JI, Steck TR (1999) Induction of the viable but nonculturable condition in Xanthomonas campestris pv. campestris in liquid microcosms and sterile soil. FEMS Microbiology 30:203-208.

Goszczynska T, Serfontein JJ (1998) Milk-Tween agar, a semiselective medium for isolation and differentiation of Pseudomonas syringae pv. syringae, Pseudomonas syringae pv. phaseolicola and Xanthomonas axonopodis pv. phaseoli. Journal of Microbiological Methods 32:65-72.

Gunasekera TS, Attfield PV, Veal DA (2000) A flow cytometry method for rapid detection and enumeration of total bacteria in milk. Applied and Environmental Microbiology 66:12281232.

Hall R (1994) Compendium of bean diseases. Saint Paul MN. APS Press.

Haugland RP (2002) Handbook of fluorescent probes and research products. $9^{\text {th }}$ ed. Oregon. Eugene Molecular Probes.

Hoefel D, Grooby WL, Monis PT, Andrews S, Saint CP (2003a) A comparative study of carboxyfluorescein diacetate succinimidyl ester as indicators of bacterial activity. Journal of Microbiological Methods 52:379-388.

Hoefel D, Grooby WL, Monis PT, Andrews S, Saint CP (2003b) Enumeration of water-borne bacteria using viability assays and flow cytometry: a comparison to culture-based techniques. Journal of Microbiological Methods 55:585-597.

Kado CI, Heskett MG (1970) Selective media for isolation of Agrobacterium, Corynebacterium, Erwinia, Pseudomonas and Xanthomonas. Phytopathology 60:969-976.

Lebaron P, Parthuisot N, Catala P (1998) Comparison of blue nucleic acid dyes for flow cytometric enumeration of bacteria in aquatic systems. Applied and Environmental Microbiology 64:725-1730.

Malin EM, Roth DA, Belden EL (1983) Indirect immunofluorescent staining for detection and identification of Xanthomonas campestris pv. phaseoli in naturally infected bean seed. Plant Disease 67:645-647.

McClelland RG, Pinder AC (1994) Detection of Salmonella typhimurium in dairy products with flow cytometry and monoclonal antibodies. Applied and Environmental Microbiology 60:4255-4262.

McDougald D, Rice SA, Weichart D, Kjelleberg S (1998) Nonculturability: adaptation or debilitation? FEMS Microbiology Ecology 25:1-9.

Morono Y, Takano S, Miyanaga K, Tanji Y, Unno H, Hori K (2004) Application of glutaraldehyde for the staining of esteraseactive cells with carboxyfluorescein diacetate. Biotechnology Letters 26:379-383.

Neergaard P (1979) Seed Pathology. London. MacMillan Press.

Rechinger KB, Siegumfeldt H (2002) Rapid assessment of cell viability of Lactobacillus delbrueckii subsp. bulgaricus by measurement of intracellular $\mathrm{pH}$ in individual cells using fluorescence ratio imaging microscopy. International Journal of Food Microbiology 78:53-60.

Saettler AW, Perry SK (1972) Seed transmitted bacterial diseases in Michigan navy beans, Phaseolus vulgaris. Plant Disease Reportes 56:378-381.

Sheppard JW, Roth DA, Saettler AW (1989) Detection of Xanthomonas campestris pv. phaseoli in bean. In: Saettler AW, Schaad NW, Roth DA (Eds.) Detection of bacteria in seed and other planting material. Saint Paul MN. APS Press. pp. 17-29.

Toth IK, Hyman LJ, Taylor R, Birch PRJ (1998) PCR-based detection of Xanthomonas campestris pv. phaseoli var. fuscans in plant material and its differentiation from X .c. pv. phaseoli. Journal of Applied Microbiology 85:327-336.

Van Der Wolf J, Schoen CD (2004) Bacterial pathogens: detection and identification methods. Encyclopedia of Plant and Crop Science. pp. 84-88. 
N.D. Tebaldi et al.

Van Vuurde JWL, Van Den Bovenkamp GW, Birnbaum Y (1983) Immunofluorescence microscopy and enzyme-linked immunosorbent assay as potential routine tests for the detection of Pseudomonas syringae pv. phaseolicola and Xanthomonas campestris pv. phaseoli in bean seed. Seed Science and Technology 11:547-559.

TPP 9018 - Received 10 February 2009 - Accepted 26 August 2010 Section Editor: Marisa A.S.V. Ferreira 